\title{
Visitation and gnawing behaviour of Japanese honeybee Apis cerana japonica to lettuce
}

\author{
Tomoyuki YокоI \\ Laboratory of Conservation Ecology, Faculty of Life and Environmental Sciences, University of Tsukuba, \\ 1-1-1 Tennodai, Tsukuba City, Ibaraki 305-8572, Japan
}

Received 1 August 2014 - Revised 13 November 2014 - Accepted 28 November 2014

\begin{abstract}
The Japanese honeybee, Apis cerana japonica, is regarded as an important pollinator of crops and wild flowers. On the other hand, its gnawing behaviour on lettuce Lactuca spp. results in serious damage to the crop yield. Little is known about the gnawing behaviour of A. c. japonica. In the present study, field experiments were conducted to clarify the seasonality of this behaviour and the preference of $A$. c. japonica toward lettuce. The rates of lettuce damage by gnawing differed among furrows, and the maximum rate was $17 \%$, while A. c. japonica showed no preference according to lettuce type. The rate of gnawing behaviour on lettuce 31 days from seeding was significantly higher than that on lettuce at 20 days. Lettuce gnawing of $A$. c. japonica was not confirmed in spring but was seen in autumn, while there was no visitation to the lettuce by the European honeybee, Apis mellifera. These results suggested that $A$. $c$. japonica might require substances produced by lettuce in autumn for overwintering.
\end{abstract}

aggregation / Apidae / Asteraceae / biting / pest

\section{INTRODUCTION}

Bees are effective pollinators and visit plants to collect pollen and nectar for their own offspring and/or colony members (Proctor et al. 1996; Michener 2000). Humans have used both wild and/or domestic bee species as pollinators to increase crop and fruit yields (Pitts-Singer and James 2008). The economic value of insect pollination is estimated at $€ 153$ billion, and bees make a large contribution to this figure (Gallai et al. 2009).

Honeybees are useful to humans due to their crop pollination and their products, such as honey and wax (Sasaki 1999; Delaplane and Mayer 2000). There are nine honeybee species in the Apis genus, most of which are present in Asia (Radloff et al. 2011). Japan is a habitat of two

Corresponding author: T. Yokoi, tomoyoko@envr.tsukuba.ac.jp Manuscript Editor: Klaus Hartfelder honeybee species - the European honeybee, Apis mellifera Linnaeus 1758, and the Japanese honeybee, Apis cerana japonica Radoszkowski 1877. A. mellifera is a widely used agricultural pollinator, the most actively managed bee species in the world (Delaplane and Mayer 2000), and was imported into Japan for beekeeping. The Japanese honeybee is a subspecies of Apis cerana and is distributed in Japan (Sasaki 1999; Hepburn and Radloff 2011; Koetz 2013). Although some aspects of the behaviour and life history of $A$. cerana are similar to those of $A$. mellifera (Koetz 2013), this species include Japanese honeybee exhibits unique abilities, such as formation of a hot bee ball to defend against hornets (Ono et al. 1995), and high resistance to mites and bacteria (Peng et al. 1987; Sasaki 1999; Yoshiyama and Kimura 2009).

In addition, to collect food resources from flowers, A. mellifera visits various plants to collect materials of propolis, which is used for both reinforcement of the nest and as a barrier to bacteria and viruses (Seeley 1985), by gnawing the shoots of plants or leaves. A. mellifera collects 
materials of propolis from the bark and buds of various plants (e.g. Silici et al. 2007), while $A$. c. japonica workers use wax instead of propolis (Sasaki 1999). Thus, gnawing behaviour has not been reported, with the exception of the response to the pheromone of the Japanese giant hornet Vespa mandarinia japonica Radoszkowski, 1857, after their attack (Ono et al. 1995).

Yokoi (2005) reported that many workers visit fields planted with both green-head lettuce, Lactuca sativa, and red-leaf lettuce, L. sativa var. crispa, and began gnawing on leaves and at the centre of the lettuce. Lettuce is one of the most common leaf vegetable crops worldwide (FAO 2014) and does not require pollinators. This unexpected visitation and gnawing by $A$. c. japonica affects the quality of the product and productivity of farmers. However, little is known about the gnawing behaviour of the Japanese honeybee. To clarify the current status of lettuce damage, this study investigated the seasonality of the behaviour and preference for lettuce according to degree of maturation.

\section{MATERIALS AND METHODS}

\subsection{The current status of lettuce gnawing behaviour in the field}

The data regarding $A$. c. japonica visiting the lettuce field were collected in Japan. There are two planting seasons for lettuce: spring season is from early April to late May, and autumn season is from September to October. Therefore, data were collected from both seasons. The data were obtained in two ways: direct confirmation or from common informers. Five points were confirmed for each datum: date, place, type of lettuce (green head or red leaf), visiting bee species (Japanese or European), and gnawing behaviour (gnawed or not).

\subsection{Rate of lettuce damage by gnawing by Japanese honeybees}

The present study was conducted in the farm of the Field Science Center of Okayama University, Okayama, Japan $\left(34^{\circ} 41^{\prime} 8.28^{\prime \prime} \mathrm{N}, 133^{\circ} 54^{\prime} 48.30^{\prime \prime}\right.$

E) (Figure 1a). Observations took place on 26
October 2010 at 10:00-14:00 on a day with sunshine and cloud. The field contained two types of lettuce in six burrows: green head lettuce, L. sativa, and red leaf lettuce, L. sativa var. crispa. The degree of maturation of lettuce was classified into three stages according to the number of days since seeding: 20, 31, and 41 days. The rate of lettuce damage was investigated on 26 October 2010. As part of the leaf and the centre of the lettuce became black after gnawing by workers (Yokoi 2005), the numbers of damaged lettuce in which a colour change was found on leaves and/or the centre of the lettuce were recorded. Farmers planted four vegetables at the side of the lettuce field: Qing-geng-cai Brassica rapa var. chinensis, Komatsuna B. rapa var. perviridis, Spinach Spinacia oleracea L., and Mizuna $B$. rapa var. nipposinica. They used a small volume of insecticide (Affirm; Syngenta) to prevent aphid and cutworm damage. The location of lettuce planting was changed each year to avoid replant failure.

\subsection{Statistical analysis}

The JMP statistical software ver. 11 (SAS Institute Inc., Cary, NC) was used for statistical analyses. Fisher's exact probability test was used to compare the differences in percentage of damaged lettuce among growth periods. Logistic regression analysis was conducted to determinate whether the occurrence of gnawing behaviour differed according to type of lettuce (green head or red leaf), season (spring or autumn), and site as fixed effects. The occurrence of gnawing behaviour was classified into two patterns: yes or no. When both spring and autumn season data could not be confirmed in the site, the data were removed from the statistical analysis.

\section{RESULTS}

\subsection{Current status of lettuce gnawing behaviour in the field}

Fifteen data regarding gnawing behaviour were obtained from eight sites in Japan (Table I). The visitation of lettuce by $A$. c. japonica was confirmed in eight sites of three districts in Japan. 

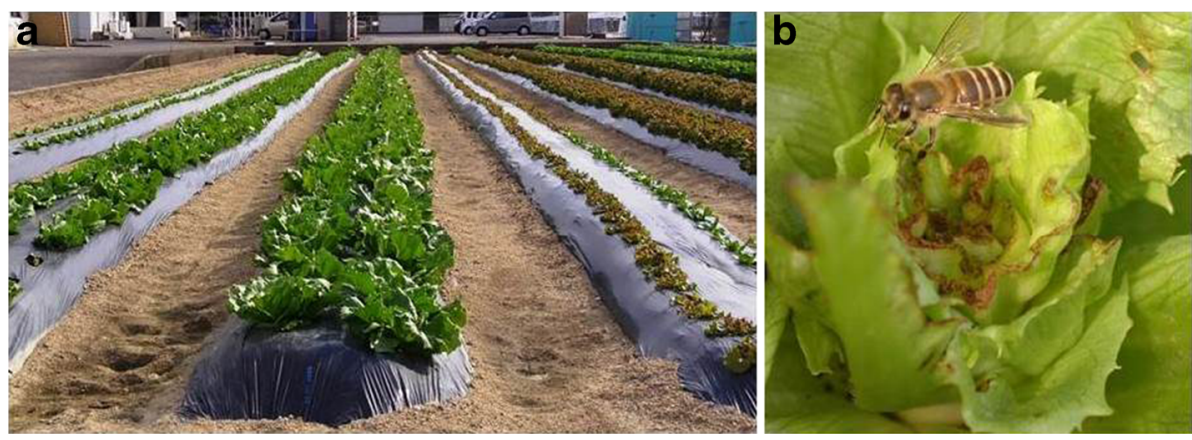

Figure 1. Lettuce field planted with green-head and red-leaf lettuce (a), and gnawing behaviour of A. c.japonica on the lettuce (b).

There was no visitation of the lettuce by European honeybees at any of the sites. Both season data were obtained from three site; Shimamoto-cho in Osaka Prefecture, Okayama city in Okayama Prefecture, and Motegi-cho in Tochigi Prefecture.
The occurrence of gnawing behaviour was significantly related to season (logistic regression analysis, $P<0.001$ ), while there was no difference between the types of lettuce (Table II). Although most farmers cultivated lettuce in both seasons,

Table I. Distribution and seasonality of gnawing behaviour records for A. c. japonica in Japan.

\begin{tabular}{|c|c|c|c|c|c|c|}
\hline District & Observation site & Year & Season & Type of lettuce & $\begin{array}{l}\text { Visitation to } \\
\text { the lettuce }\end{array}$ & $\begin{array}{l}\text { Gnawing behavior } \\
\text { of honeybee }\end{array}$ \\
\hline \multirow[t]{7}{*}{ Kansai } & $\begin{array}{l}\text { Nagaokakyo City, } \\
\text { Kyoto Pref. }\end{array}$ & 2005 & Autumn & $\begin{array}{l}\text { Red-leaf and } \\
\text { green head }\end{array}$ & Yes & Yes \\
\hline & $\begin{array}{l}\text { Moriguchi City, } \\
\text { Osaka Pref. }\end{array}$ & 2008 & Autumn & Green head & Yes & Yes \\
\hline & $\begin{array}{l}\text { Kihoku-cho, Mie } \\
\text { Pref. }\end{array}$ & 2010 & Autumn & Green head & Yes & Yes \\
\hline & \multirow[t]{3}{*}{$\begin{array}{l}\text { Shimamoto-cho, } \\
\text { Osaka, Pref. }\end{array}$} & 2011 & Autumn & $\begin{array}{r}\text { Red-leaf and } \\
\text { green head }\end{array}$ & Yes & Yes \\
\hline & & 2012 & Spring & $\begin{array}{l}\text { Red-leaf and } \\
\text { green head }\end{array}$ & No & No \\
\hline & & 2012 & Autumn & $\begin{array}{r}\text { Red-leaf and } \\
\text { green head }\end{array}$ & No & No \\
\hline & $\begin{array}{l}\text { Kozagawa-cho, } \\
\text { Wakayama Pref. }\end{array}$ & 2013 & Autumn & Red-leaf & Yes & Probably yes \\
\hline \multirow[t]{5}{*}{ Chugoku } & \multirow[t]{5}{*}{$\begin{array}{l}\text { Okayama City, } \\
\text { Okayama Pref. }\end{array}$} & 2009 & Autumn & $\begin{array}{r}\text { Red-leaf and } \\
\text { green head }\end{array}$ & Yes & Yes \\
\hline & & 2010 & Autumn & $\begin{array}{r}\text { Red-leaf and } \\
\text { green head }\end{array}$ & Yes & Yes \\
\hline & & 2011 & Spring & $\begin{array}{l}\text { Red-leaf and } \\
\text { green head }\end{array}$ & No & No \\
\hline & & 2011 & Autumn & $\begin{array}{l}\text { Red-leaf and } \\
\text { green head }\end{array}$ & Yes & Yes \\
\hline & & 2012 & Spring & $\begin{array}{l}\text { Red-leaf and } \\
\text { green head }\end{array}$ & No & No \\
\hline \multirow[t]{3}{*}{ Kanto } & $\begin{array}{l}\text { Hitachiomiya City, } \\
\text { Ibaraki Pref. }\end{array}$ & 2009 & Autumn & Green head & Yes & Yes \\
\hline & \multirow{2}{*}{$\begin{array}{l}\text { Motegi-cho, Tochigi } \\
\text { Pref. }\end{array}$} & 2013 & Autumn & Green head & Yes & Yes \\
\hline & & 2014 & Spring & Green head & No & No \\
\hline
\end{tabular}


Table II. Logistic regression analysis of gnawing behaviour.

\begin{tabular}{lccl}
\hline Source & $d . f$. & $\chi^{2}$ & $P$ \\
\hline Season & 1 & 13.863 & 0.0002 \\
Site & 2 & 4.866 & 0.088 \\
Type of lettuce & 1 & 0 & 1 \\
\hline
\end{tabular}

visitation of lettuce by Japanese $A$. c. japonica was confirmed only in autumn.

\subsection{Rate of lettuce damage by gnawing of Japanese honeybees}

The visitation of lettuce by $A$. c. japonica was confirmed from the middle of September 2010 (Figure 1b). Three and/or two individuals visited each lettuce on all days and did not visit other vegetables near the lettuce. They crawled into the lettuce and gnawed the edges of the leaves and centre of the lettuce. There were 1619 lettuces in the farm, which consisted of 814 green-head and 805 red-leaf type. The percentage of damaged lettuce 31 days after seeding $(4.1 \%, n=293)$ was significantly higher than that of lettuce 20 days after $(0 \%, n=272)$ in green head (Fisher's exact probability test, $P<0.0005)$. In red leaf, the percentage of damaged lettuce 31 days after seeding
$(9.1 \%, n=444)$ was significantly higher than that of lettuce 20 days after $(0 \%, n=361)$ (Fisher's exact probability test, $P<0.0001)$. In the greenhead type, the percentage of damaged lettuce was not different at 31 and 41 days after seeding. However, the percentage of damaged lettuce by gnawing honeybees reached $17.4 \%$ and showed differences among the furrows (Figure 2).

\section{DISCUSSION}

Honeybees are essential pollinators for crop production (Delaplane and Mayer 2000; Gallai et al. 2009), while they present a danger to human life and health due to their sting, aggressiveness, and unexpected nest building in homes (Matsuura 2005). The Asian honeybee, A. cerana, is regarded as an excellent crop pollinator for a large variety of fruit and vegetable crops (Partap 2011). The floral resources and life history of the Japanese honeybee have been investigated (e.g. Nagamitsu and Inoue 1999; Sasaki 1999). Honeybees have not been classified as a "pest insect" in agricultural systems, although they are sometimes the victim of pesticides used for other insects. This is the first report of the assessment of gnawing behaviour of honeybees toward lettuce. Visitation by Japanese honeybees results in serious damage to crop production with a maximum
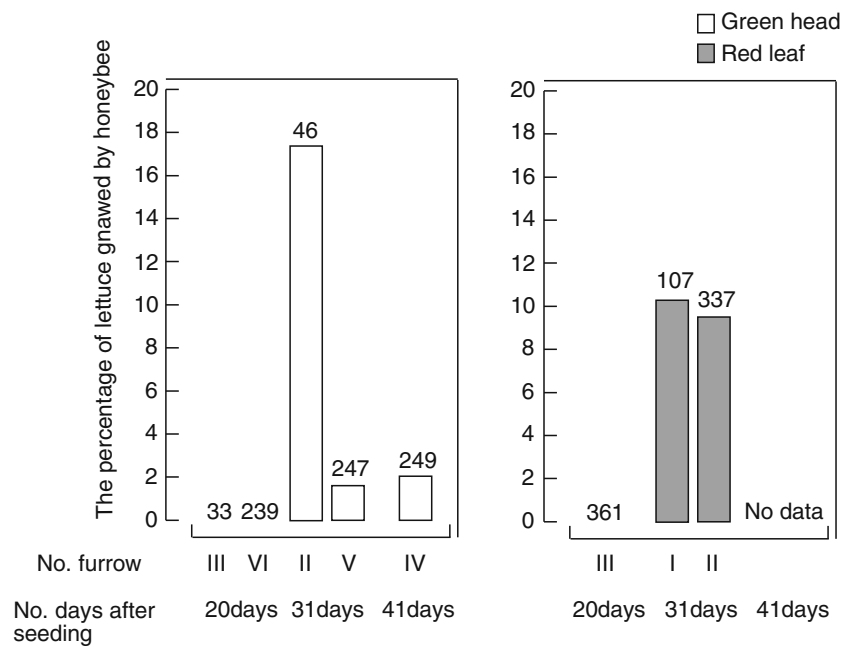

Figure 2. The percentage of lettuce gnawed by A. c. japonica with number of days elapsed from seeding. White and grey bars represent green-head and red-leaf lettuce, respectively. 
rate of $17.4 \%$. Moreover, A. c. japonica workers preferred lettuce at 31 or 41 days after seeding, which is the optimum stage for harvesting. Therefore, honeybees appear to have the ability to select mature lettuce as well as searching for nectar-rich flowers. This study demonstrated that the Japanese honeybee visits lettuce only in the autumn. While A. c. japonica is known to prepare floral resources for overwintering, little is known about other collected substances and collecting behaviour in autumn (Sasaki 1999). As many workers visit lettuce on all days, substances produced by lettuce during the autumn may be needed for overwintering of $A$. c. japonica.

The European honeybee, A. mellifera, gnaws on plants and collects substances for propolis on their hind legs (Silici et al. 2007). In the present study, workers of $A$. c. japonica were seen to gnaw the centre and leaves of lettuce, suggesting that they gain nutrition in this way. They showed no preference for a type of lettuce, because they visited and gnawed both the green-head and redleaf type. These observations raise questions regarding the types of nutrition that they require. Lettuce contains sesquiterpene lactones, i.e. lactucopicrin, which are related to the bitter taste (Price et al. 1990), while no unique nutritional substances have been found, and it has low vita$\min \mathrm{C}$ and $\beta$-carotene contents (Horie 2010). The amount of lactucopicrin is higher in the centre than in other parts of lettuce (Arakawa et al. 2009), suggesting that the Japanese honeybee may ingest this substance. In addition, the leaves of other Asteraceae plants are also targets of gnawing by honeybees (Yokoi 2005). Thus, chemical analyses of the contents of Asteraceae plants, including lettuce, are required to clarify the behavioural significance of the lettuce-gnawing behaviour.

There are several behavioural differences between A. c. japonica and A. mellifera (Sasaki 1999), and lettuce gnawing by $A$. c. japonica was confirmed in many areas of Japan, while A. mellifera did not visit lettuce in either season. These results suggest that substances present in lettuce are needed by only A. c. japonica. Although the role of the substance(s) present in lettuce and other Asteraceae plants is unknown, this honeybee species may require this substance(s) before overwintering. Further fundamental studies are required to resolve the damage to lettuce production by $A$. c. japonica.

\section{ACKNOWLEDGMENTS}

I greatly thank Dr. M. Katsuki (Faculty of Life and Environmental Sciences, University of Tsukuba) for valuable comments. I am grateful to $\mathrm{H}$. Machii, T. Miyashita, J. Nakamura, K. Nakata, M. Nakata, A. Oomori, M. Sugahara, Y. Suzaki and members of the Field Science Center of Okayama University for their help to collect the field data. This work was supported by the Program to Disseminate Tenure Tracking System, University of Tsukuba.

L'abeille japonaise Apis cerana japonica visite les laitues et les grignote

Apidae / Asteraceae / morsure / ravageur / agrégation / Japon

Besuch und Nageverhalten der japanischen Honigbiene Apis cerana japonica an Kopfsalat

Aggregation / Apidae / Asteraceae / Nagen / Schädling

\section{REFERENCES}

Arakawa, K., Minami, M., Nakamura, K., Matsushima, K., Nemoto, K. (2009) Differences of sesquiterpene lactones content in different leaf parts and head formation stages in lettuce. Hort. Res. Japan 8, 13-17

Delaplane, K.S., Mayer, D.F. (2000) Crop pollination by bees. CABI publishing, Oxon

FAO (2014) [online] http://faostat3.fao.org/faostat-gateway/go/to/home/E. (accessed on 30 July 2014).

Gallai, N., Salles, J.-M., Settele, J., Vaissière, B.E. (2009) Economic valuation of the vulnerability of world agriculture confronted with pollinator decline. Ecol. Econ. 68, $810-821$

Hepburn, H.R., Radloff, S.E. (2011) Biogeography. In: Hepburn, R., Radloff, S.E. (eds.) Honeybees of Asia, pp. 51-68. Springer Verlag, Berlin

Horie, H. (2010) Analysis of lactucopicrins (bitter compounds) in lettuce by high-performance liquid chromatography. Bull. Natil. Inst. Vegetable and Tea Science. 9, 189-195

Koetz, A.H. (2013) Ecology, behaviour and control of Apis cerana with a focus on relevance to the Australian Incursion. Insects 4, 558-592 
Matsuura, M. (2005) Biology and control of social wasps and bees in urban environments. Tamagawa University, Honeybee Science Research Center (In Japanese)

Michener, C.D. (2000) The bees of the world. Johns Hopkins University Press, Baltimore, MDA

Nagamitsu, T., Inoue, T. (1999) Difference in pollen sources of Apis cerana japonica and Apis mellifera in a primary beech forest in central Japan. J. Apic. Res. 38, $71-78$

Ono, M., Igarashi, T., Ohno, E., Sasaki, M. (1995) Unusual thermal defence by a honeybee against mass attack by hornets. Nature 377, 334-336

Partap, U. (2011) The pollination role of honeybees. In: Hepburn, R., Radloff, S.E. (eds.) Honeybees of Asia, pp. 227-256. Springer Verlag, Berlin

Peng, Y.S.C., Fang, Y., Xu, S., Ge, L. (1987) The resistance mechanism of the Asian honey bee, Apis cerana Fabr., to an ectoparasitic mite, Varroa jacobsoni Oudemans. J. Invert. Pathol. 49, 54-60

Pitts-Singer, T.L., James, R.R. (2008) Bees in nature and on the farm. In: James, R.R., Pitts-Singer T.L. (eds.) Bee pollination in agricultural ecosystems, pp. 3-9. Oxford University Press, New York

Price, K.R., Dupont, M.S., Shepherd, R., Chan, H.W.-S., Fenwick, G.R. (1990) Relationship between the chemical and sensory properties of exotic salad crops-coloured lettuce (Lactuca sativa) and chicory (Cichorium intybus). J. Sci. Food Agric. 53 , 185-192

Proctor M. C. F., Yeo P., Lack A. (1996) The natural history of pollination. Timber Press, Portland

Radloff, S.E., Hepburn, H.R., Engel, M.S. (2011) The Asian species of Apis. In: Hepburn, R., Radloff, S.E. (eds.) Honeybees of Asia, pp. 1-22. Springer Verlag, Berlin

Sasaki, M. (1999) Wonders of the Japanese honeybee Biology of Northernmost Apis cerana. Kaiyusya, Japan (In Japanese)

Seeley, T.D. (1985) Honeybee ecology. Princeton University Press, Princeton

Silici, S., Ünlü, M., Vardar-Ünlü, G. (2007) Antibacterial activity and phytochemical evidence for the plant origin of Turkish propolis from different regions. World J. Microbiol. Biotechnol. 23, 1797-1803

Yokoi, T. (2005) Observation of honeybee Apis cerana gnawing the lettuce. Honeybee Sci. 26, 98-100

Yoshiyama, M., Kimura, K. (2009) Bacteria in the gut of Japanese honeybee, Apis cerana japonica, and their antagonistic effect against Paenibacillus larvae, the causal agent of American foulbrood. J. Invertebr. Pathol. 102, 91-96 